\title{
Effect of Chronic Dietary Copper Exposure on Haematology and Histology of Common Carp (Cyprinus carpio L.)
}

\author{
${ }^{* 1}$ AJANI, E K; ${ }^{2}$ AKPOILIH, B U \\ ${ }^{I}$ Department of Wildife and Fisheries Management, University of Ibadan, Ibadan, ${ }^{2}$ Department of Biological Sciences, Novena University, \\ Ogume, Delta State, Nigeria
}

\begin{abstract}
Effects of exposure of common carp (Cyprinus carpio L.) to dietary copper and its recovery rate were investigated with the aim of determining the haematological and histological impact. In this study, fish were fed elevated copper diets (1000 $\mathrm{mgCukg}^{-1}$ and $2000 \mathrm{mgCukg}^{-1}$ as diet 2 and diet 3 respectively,) and control diet $\left(5 \mathrm{mgCukg}^{-1}\right.$, diet 1$)$ for 42 days and were then fed the control diet for a further 21days.To make dietary preparations of the copper concentrations, $1.1722 \mathrm{~g}$ and $2.3503 \mathrm{~g}$ of $\mathrm{CuSO}_{4} .5 \mathrm{H}_{2} \mathrm{O}$ (AnalaR grade), dissolved in $35 \mathrm{ml}$ deionised water, were mixed with each of $300 \mathrm{~g}$ of the commercially available pellet diet, which contained $5 \mathrm{mgCu} / \mathrm{kg}$ of feeds, to make $1000 \mathrm{mgCu} / \mathrm{kg}$ and $2000 \mathrm{mgCu} / \mathrm{kg}$ of feed, respectively. Fish fed diet $2\left(1000 \mathrm{mgCukg}^{-1}\right)$ showed significant increase $(\mathrm{p}<0.05)$ in haematocrit, red blood cell, white blood cell and neutrophil and a significant decrease $(\mathrm{p}<0.05)$ in lymphocyte and mean cell haemoglobin compared to diet 1 and diet 3 . This increase in blood indices is indicative of stress onset to which fish fed diet $2\left(1000 \mathrm{mgCukg}^{-1}\right)$ is subjected. Fish fed diet $3\left(2000 \mathrm{mgCukg}^{-1}\right)$ showed significant reduction in haematocrit, red blood cell, white blood cell and increased lymphocyte $(\mathrm{p}<0.05)$ and became anaemic with severe skin discoloration, indicative of a worsening effect of excess dietary copper exposure on the fish. Gills and intestines of both diet 2 and diet 3 were normal during and after exposure, but fatty change was observed throughout the experiment. This was confirmed by a 4.4 and 7.1-fold increase in the liver copper of fish fed diet 2 and diet 3 respectively compared to control $(\mathrm{p}<0.05)$ and a further 1.8 - and 1.2 -fold increase post exposure, indicative of delayed hepatotoxicity. In conclusion, increasing the copper level of common carp beyond tolerable dose impacted negatively on the fish. @JASEM
\end{abstract}

Copper is an essential micronutrient for vertebrate animals especially fish. It has numerous functions in cellular biochemistry including vital roles in cellular respiration, and a cofactor for over 30 different enzymes (Linder 1991). Copper compounds are used for prophylactic purposes to control fish diseases and parasites (Moore et al., 1984). They also used to control algae, kill slugs and snails in irrigation water systems and municipal water treatment systems. Copper is a heavy metal with density greater than $5 \mathrm{~g} / \mathrm{cm}^{3}$, thus it is toxic and poisonous in relatively high concentrations. It is non biodegradable but easily assimilated and bio-accumulated (Okoye et al., 1991). Elevated levels of copper may become acutely or chronically toxic to aquatic lives. Chronic effects include reduced growth, shorter lifespan, reproductive problems, reduced fertility and behavioural changes. Copper deficiency leads to physiological disturbances, symptoms which include depression of growth, anaemia, bowing of legs, spontaneous fractures, ataxia of new born, cardiac and vascular disorders, depigmentation, decrease in some organs weight, depressed reproductive performance including egg production (Linder 1991) and tissue accumulation (Shaw and Handy, 2006).

Since most aquatic organisms eat plankton, detritus and sediment which they assimilate, the toxic effect of heavy metals such as copper is also indirect because of adsorption of copper by these particulate materials. The first food of fish is plankton, which serves as the bedrock of primary producers in the aquatic food chain. Since copper is essential for all life processes, plants absorbing it. The presence of excessive metal in water at avoidable concentration does not favour plankton growth since metals are rapidly adsorbed in particulate materials (Moore et al., 1984).

The common carp, a benthic omnivore, is native to Asia and Eastern Europe (Taylor and Mahon, 1977). It is reputed as a popular food fish and a highly cultivable species with year round breeding under tropical and subtropical conditions. The common carp also plays an important role in polyculture systems in seasonal reservoirs and ponds (Chakrabarty, 1982). It is the only exotic carp species that is known to breed naturally in lake with high fecundity and hatchability (Nathaniel and Edirisinghe 2001). It has been introduced into environments worldwide and can grow to a maximum length of 5 feet $(1.5 \mathrm{~m})$, a maximum weight of over $80 \mathrm{lb}(37.3 \mathrm{~kg})$, and an oldest record age of at least 65 years. This age longevity of common carp makes it good for chronic toxicity test (Panek 1987).

Although they are very tolerant to most condition, the common carp prefer large bodies of slow or standing water and soft, vegetable sediments. This makes it not unaffected by pollution from heavy metals since they eat any thing near the river bank and its bottom, thus ingesting contaminated food and water during feeding (Alabaster and Lloyd, 1980). There have been many reports on the effect of some heavy metals on some common fish species. This present study will examine the effect of chronic dietary copper toxicity on the haematology and histology of common carp and establish a threshold for dietary copper toxicity in the test fish. 


\section{MATERIALS AND METHODS}

Experimental Design: Common carp were purchased from Agricultural Development Programme fish farm in Ibadan, Nigeria. They were then placed under laboratory conditions in fish holding tanks with water temperature $27.4 \pm 0.42^{\circ} \mathrm{C}$ and left unfed in the first 2 days to adapt to a change in environment before feeding them with normal fish diet. One hundred and seventeen (117) fish of average weight $19.43 \pm$ $14.09 \mathrm{~g}$ were then distributed in nine plastics of 52 litres each in a water renewal method with 13 fish per tank and were fed a control diet with no added copper to saturation for 14 days in order to acclimatize them to experimental conditions.

While fish in the $1^{\text {st }}, 2^{\text {nd }}$, and $3^{\text {rd }}$ containers remained on the control diet, fish in the $4^{\text {th }}, 5^{\text {th }}$ and $6^{\text {th }}$ containers were fed copper-loaded diets $(1000 \mathrm{mg} / \mathrm{kg}$ dry weight feed) and fish in the $7^{\text {th }}, 8^{\text {th }}$ and $9^{\text {th }}$ containers were also fed copper loaded diet $(2,000 \mathrm{mg}$ cupper/kg dry weight feed) for 42 days. This was then was then followed by a 21 day recovery period with all containers fed the control diet (no added copper). Fish were fed to satiation twice a day in the morning and evening. Care was taken to ensure that no uneaten food remained in the tanks during feeding and copper did not leach from the feed. To achieve these objectives, water was constantly and completely changed daily with fresh well water added and uneaten food removed after satiation was noticed. Daily feed intake was calculated and copper concentrations in the different tank were measured in the analysis of water quality. Water quality is shown in table 1 . Fish were not fed the day before sampling times in order to empty the gut and to facilitate dissection.

Preparation of Experimental Diet: The experimental diet was formulated by starch coating of the commercial feed with copper sulphate $\left(\mathrm{CuSO}_{4}\right)$. In order to achieve a nominal copper concentration of $1000 \mathrm{mgCukg}^{-1}$ feed, $1.1722 \mathrm{~g}$ of $\mathrm{CuSO}_{4} \cdot 5 \mathrm{H}_{2} \mathrm{O}$ (AnalaR grade, BDH, poole, UK) was dissolved in $35 \mathrm{ml}$ of deionised water with $1.2 \mathrm{~g}$ of starch to bind the copper to the feed. The starch solution was gradually sprayed onto $300 \mathrm{~g}$ of the commercial diet and mixed in a container to ensure even mixing of the feed. The starch coat dried within minutes, and the copper diet was stored in airtight containers at $20^{\circ} \mathrm{C}$ to prevent lipid oxidation. The other copper supplemented diet $(2000 \mathrm{mgCu} / \mathrm{kg})$ was similarly treated, but required higher $\mathrm{CuSO}_{4} .5 \mathrm{H}_{2} \mathrm{O}$. In order to achieve a nominal copper concentration of $2000 \mathrm{mgCu} / \mathrm{kg}$ feed, $2.3503 \mathrm{~g}$ of $\mathrm{CuSO}_{4} 5 \mathrm{H}_{2} \mathrm{O}$ was also dissolved in $35 \mathrm{ml}$ of deionised water with $1.2 \mathrm{~g}$ of starch to bind the copper to the feed and then mixed thoroughly. The starch solution was sprayed onto $300 \mathrm{~g}$ of the pre-treated diet and stored at $20^{\circ} \mathrm{C}$ after drying. The control diet was similarly treated except that no copper was added. The copper contents of the diets were confirmed by atomic absorption spectrophotometer (210 VGP).

Haematology: Fish for haematology were collected (2 fish per tank, randomly sampled, or 6 fish/ treatment) at the beginning of the experiment and at the end (42 days). They were kept in clean aerated water and whole blood collected through the heart into heparinised syringes and dispensed into $\mathrm{k}_{2}$ EDTA blood sample bottles. The blood, collected using the heparinised syringe fitted with an insulin needle (0.5diameter) was taken in triplicate for each treatment before and after the exposure period (42 days). Haematological parameters such as packed cell volume, haemoglobin, red blood cell count, white blood cells count, mean cell volume, mean cell haemoglobin concentration, mean cell haemoglobin were determined according to the methods described by Jain (1986).No blood samples were collected during recovery phase in view of the haematology determined during exposure phase.

Histology and Tissue copper: After blood sampling fish in accordance with ethnical approval, tissues were carefully dissected for histology (Handy et al, 1999). The second gill arches from opercula cavities, posterior intestine, and then liver were harvested. Half of each tissue collected was fixed (10\% buffered formaldehyde containing saline) for histology, and the other half use for tissue ion analysis was decalcified with rapid decalcifiers. These, along with liver and intestine sample, were processed for routine wax histology according to Handy et al (1999).

Microphotographs of tissues were taken by using a digital camera (Kodak V530 zoom digital).Tissue copper was also determined by digestion of sample with freshly prepared nitric acid and concentration determined with Atomic Absorption Spectrophotometry using flame photometer (model:corning 410)after dilution to volume. The actual copper was calculated as the product of ppm reading and dilution factor, which is the ratio of the volume of digest to the weight of sample digested.

\section{RESULTS AND DISCUSSION}

The physiological effects of dietary copper exposure and recovery on normal diet were studied throughout the entire length of the project. Histology (Plates 1-7), haematology (Table 2) as well as tissue ion (Table 3 and 4 ) were investigated during the two phases of the experiment (exposure and recovery). Water quality was monitored throughout the exposure phase and result showed that all parameters were within the range required and tolerated by common carp. Table 1 below shows water quality obtained during dietary copper exposure. 
Table 1: The water quality of common carp fed control diet (diet 1) and elevated copper diets (diet 2,1000mgCu/kg and diet 3 , $2000 \mathrm{mgCu} / \mathrm{kg}$ ) for 42 days.

\begin{tabular}{llll}
\hline Water Quality & $\begin{array}{l}\text { Diet } 1 \\
(\text { Control })\end{array}$ & $\begin{array}{l}\text { Diet } 2 \\
(1000 \mathrm{mgCu} / \mathrm{kg})\end{array}$ & $\begin{array}{l}\text { Diet 3 } \\
(2000 \mathrm{mgCu} / \mathrm{kg})\end{array}$ \\
\hline Temp. $\left({ }^{\circ} \mathrm{C}\right)$ & $27.67 \pm 0.03$ & $27.53 \pm 0.12$ & $27.60 \pm 0.03$ \\
$\mathrm{pH}$ & $7.93 \pm 0.02$ & $7.91 \pm 0.04$ & $7.97 \pm 0.02$ \\
$\mathrm{CO}_{2}(\mathrm{mg} / \mathrm{l})$ & $1.26 \pm 0.02$ & $1.30 \pm 0.40$ & $1.24 \pm 0.04$ \\
$\mathrm{DO}_{2}(\mathrm{mg} / \mathrm{l})$ & $6.14 \pm 0.03$ & $5.95 \pm 0.08$ & $6.18 \pm 0.07$ \\
$\mathrm{Total} \mathrm{NH}_{3}(\mathrm{mg} / \mathrm{l})$ & $3.65 \pm 0.02$ & $3.42 \pm 0.03$ & $3.32 \pm 0.02$ \\
Alkalinity $(\mathrm{mg} / \mathrm{l})$ & $41.54 \pm 0.21$ & $41.75 \pm 0.04$ & $42.02 \pm 0.02$ \\
Hardness $(\mathrm{mg} / \mathrm{l})$ & $45.68 \pm 0.03$ & $45.51 \pm 0.05$ & $45.21 \pm 0.08$ \\
Nitrate $(\mathrm{mg} / \mathrm{l})$ & $12.88 \pm 0.02$ & $12.58 \pm 0.07$ & $12.59 \pm 0.02$ \\
Calcium $(\mathrm{mg} / \mathrm{l})$ & $28.00 \pm 0.13$ & $28.14 \pm 0.04$ & $28.09 \pm 0.12$ \\
Magnesium $(\mathrm{mg} / \mathrm{l})$ & $18.95 \pm 0.28$ & $18.81 \pm 0.14$ & $18.72 \pm 0.02$ \\
Potassium $(\mathrm{mg} / \mathrm{l})$ & $10.71 \pm 0.04$ & $10.81 \pm 0.06$ & $10.54 \pm 0.03$ \\
Sodium $(\mathrm{mg} / \mathrm{l})$ & $18.12 \pm 0.11$ & $18.01 \pm 0.05$ & $18.20 \pm 0.07$ \\
Copper $(\mathrm{mg} / \mathrm{l})$ & $0.02 \pm 0.01$ & $0.03 \pm 0.02$ & $0.01 \pm 0.03$ \\
\hline \multicolumn{2}{c}{ Data are presented as means $\pm \mathrm{S} . \mathrm{E}, \mathrm{n}=3$ per value $\mathrm{n}=$ number of samples per parameter }
\end{tabular}

Table 2: Haematological parameters of Common carp fed diet 1 (control diet), diet $2(1000 \mathrm{mgCu} / \mathrm{Kg})$ and diet $3(2000 \mathrm{mgCu} / \mathrm{Kg})$ for 42 day.

\begin{tabular}{lllll}
\hline Parameter & Initial & Diet 1 (Control) & Diet 2 (1000mgCu/kg) & $\begin{array}{l}\text { Diet 3 } \\
(2000 \mathrm{mgCu} / \mathrm{kg})\end{array}$ \\
\hline $\mathrm{PCV}(\%)$ & $22.0 \pm 1.53^{\mathrm{a}}$ & $22.0 \pm 1.53^{\mathrm{a}}$ & $28.7 \pm 2.19^{\mathrm{b}}$ & $20.3 \pm 0.83^{\mathrm{a}}$ \\
$\mathrm{Hb}(\mathrm{g} / \mathrm{dl})$ & $7.07 \pm 1.52^{\mathrm{a}}$ & $7.7 \pm 0.44^{\mathrm{a}}$ & $8.07 \pm 1.31^{\mathrm{a}}$ & $6.77 \pm 0.43^{\mathrm{a}}$ \\
$\mathrm{RBC}\left(10^{6} / \mathrm{mm}^{3}\right)$ & $1.51 \pm 0.01^{\mathrm{a}}$ & $1.74 \pm 0.03^{\mathrm{a}}$ & $2.76 \pm 0.08^{\mathrm{b}}$ & $1.58 \pm 0.11^{\mathrm{a}}$ \\
$\mathrm{WBC}\left(10^{3} / \mathrm{mm}^{3}\right)$ & $1.38 \pm 0.06^{\mathrm{a}}$ & $1.09 \pm 0.56^{\mathrm{a}}$ & $1.63 \pm 0.16^{\mathrm{b}}$ & $1.20 \pm 0.08^{\mathrm{a}}$ \\
Lymphocyte $(\%)$ & $69.0 \pm 0.06^{\mathrm{a}}$ & $68.3 \pm 0.41^{\mathrm{a}}$ & $64 \pm 1.15^{\mathrm{b}}$ & $67.3 \pm 0.90^{\mathrm{a}}$ \\
Neutrophil $(\%)$ & $28.0 \pm 0.06^{\mathrm{a}}$ & $28.0 \pm 0.58^{\mathrm{a}}$ & $33.7 \pm 1.45^{\mathrm{b}}$ & $30.0 \pm 1.0^{\mathrm{a}}$ \\
MCV (fl) & $145.27 \pm 4.57^{\mathrm{a}}$ & $134.08 \pm 10.8^{\mathrm{b}}$ & $105.13 \pm 11.39^{\mathrm{b}}$ & $128.78 \pm 2.73^{\mathrm{b}}$ \\
$\mathrm{MCHC}(\%)$ & $31.9 \pm 1.84^{\mathrm{a}}$ & $32.14 \pm 1.49^{\mathrm{a}}$ & $28.69 \pm 7.33^{\mathrm{a}}$ & $33.3 \pm 2.09^{a}$ \\
& & & \\
$\mathrm{MCH}(\mathrm{Pg})$ & $44.97 \pm 1.84^{\mathrm{a}}$ & $42.94 \pm 3.31^{\mathrm{a}}$ & $28.89 \pm 2.46^{\mathrm{b}}$ & $42.95 \pm 3.07^{\mathrm{a}}$ \\
\hline
\end{tabular}

Data are presented as means \pm S.E $(\mathrm{n}=3$ per value), Letter with same superscript in the same row are not significant $(\mathrm{p}>0.05)$. PCV=packed cell volume, $\mathrm{Hb}=$ haemoglobin, $\mathrm{RBC}=$ red blood cell, $\mathrm{WBC}=$ white blood cell, $\mathrm{MCV}=$ Mean corpuscular volume, $\mathrm{MCHC}=$ mean cell haemoglobin concentration, $\mathrm{MCH}=$ mean cell haemoglobin

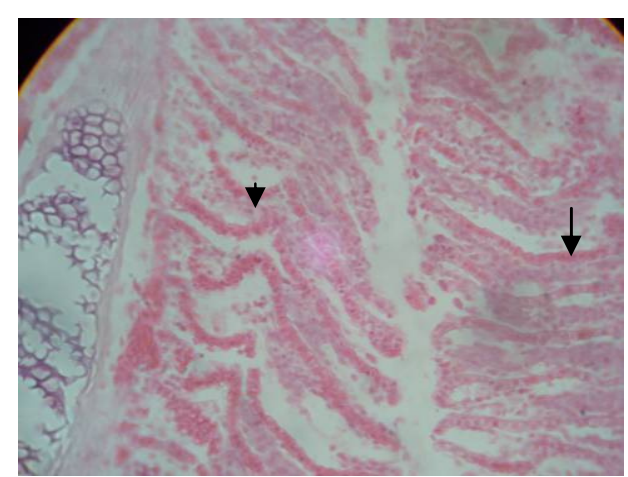

Fig 1: Histology of Common carp gills before dietary copper exposure showing mucoid epithelium (Arrow head) and secondary filament (Arrow) with no visual lesion. H+E×400.
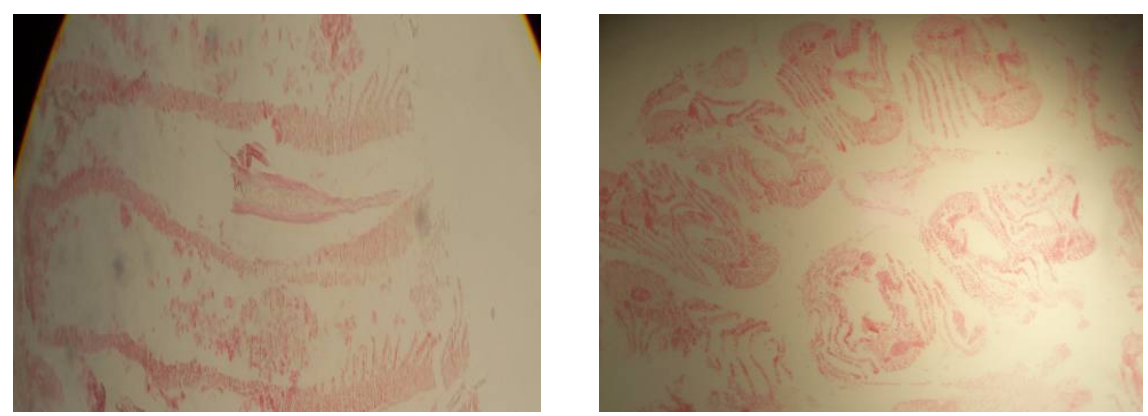

Fig 2: Histology of common carp gill fed for 42days diet 2(left) and diet 3(right) showing normal epithelia linings (Arrow head) and lamella (Arrow) with no visual lesion. $\mathrm{H}+\mathrm{E} \times 400$. 


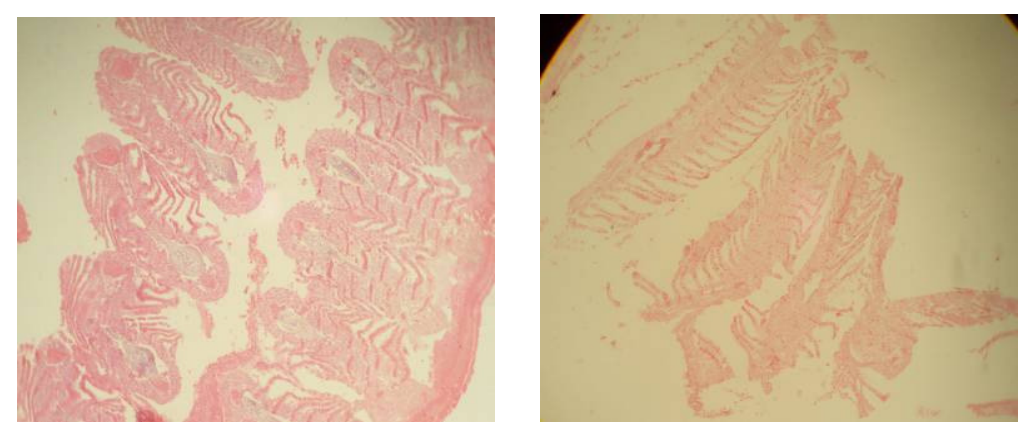

Fig 3: Histology of common carp gill (diet 2,left) and (diet 3,right) gill fed the control diet for 21 days after dietary copper exposure, showing lamella with no visual lesion.
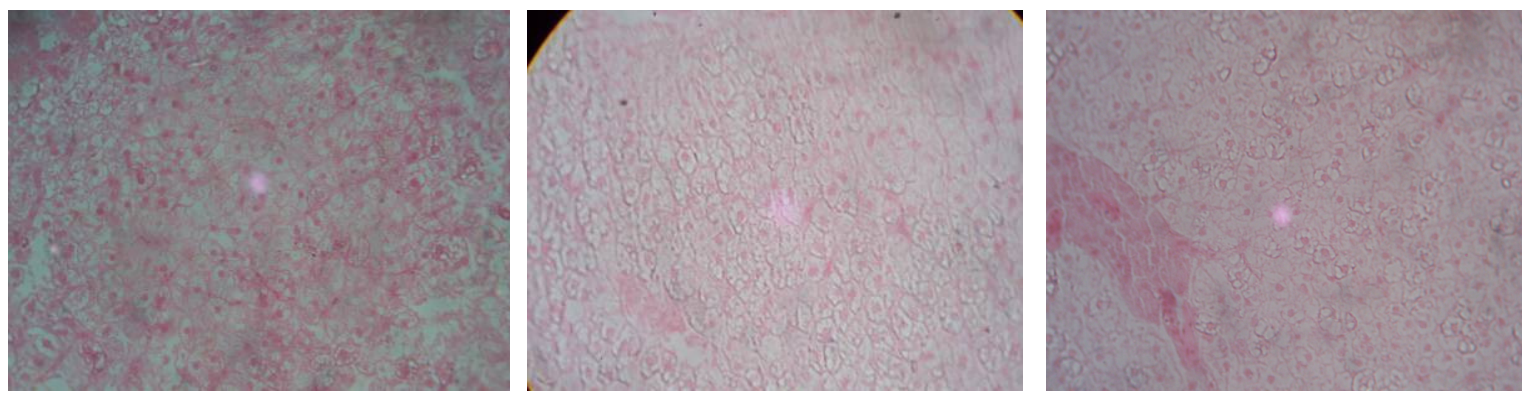

Fig 4: Histology of common carp liver fed diet 1 (left, with arrow showing liver cell), diet 2 (middle) and diet 3(right) for 42 days with diet 2 and diet 3 showing vacuolation of hepatocytes (Arrow head) $\mathrm{H}+\mathrm{E} \times 400$
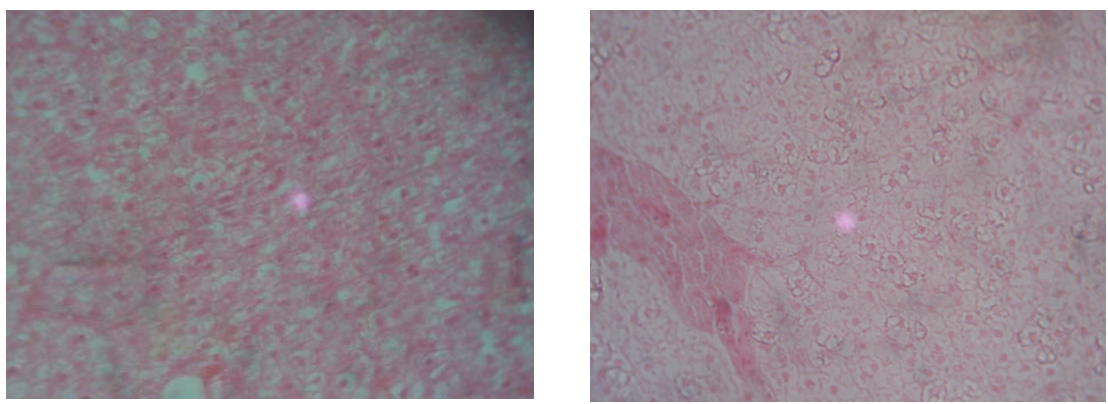

Fig 5: Histology of common carp liver fed diet 2(left) and diet 3(right) liver exposed to control diet (normal diet) for 21 days showing vacuolation of hepatocytes (fatty change). $\mathrm{H}+\mathrm{E} \times 400$.
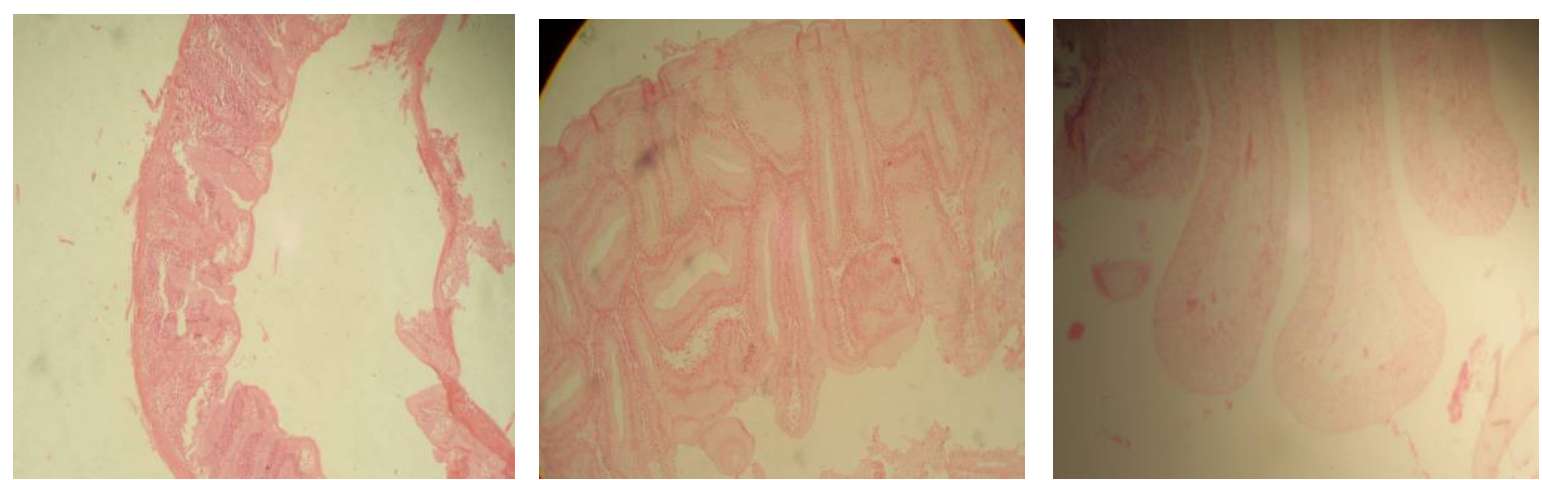

Fig 6: Histology of common carp intestine fed control diet (left), diet 2 (middle), and diet 3 (right) for 42 days showing mucoid epithelial cell (Arrow head) and intestinal folds (Arrow) with no visual lesions in all tissues examined.H+E×400. 

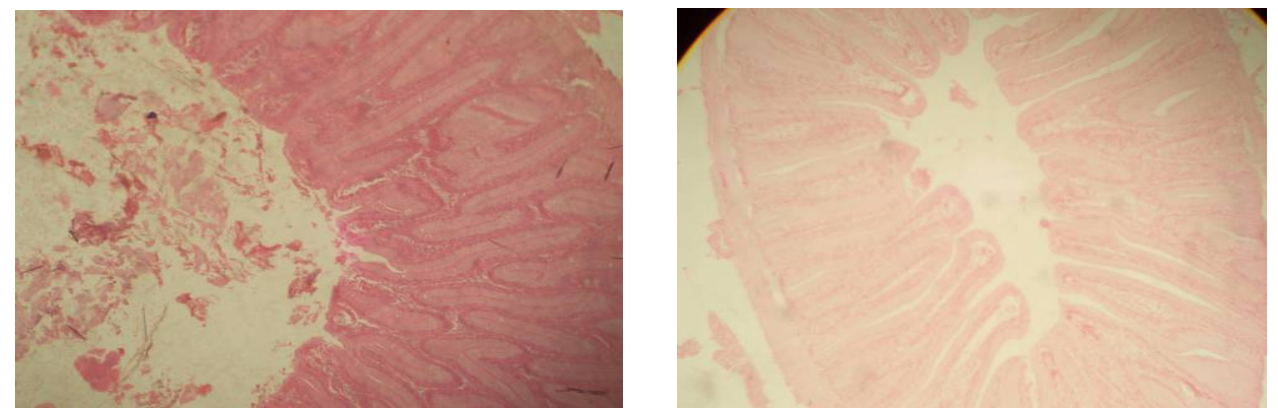

Fig 7: Histology of common carp intestine fed diet 2 (left) and diet 3 (right) fish intestine after exposure to control diet(normal diet)for 21 days showing no visual lesion in both lumens(Arrow head) and mucosa(Arrow) $\mathrm{H}+\mathrm{E} \times 400$

Table 3 Total Copper concentration in gill, liver and intestine of common carp fed control (diet 1), 1000mg/kg (diet 2) and 2000mg/kg (diet 3) after 42 days.

\begin{tabular}{llll}
\hline Treatment & Gill & Liver & Intestine \\
\hline Initial & $11.63 \pm 0.37^{\mathrm{a}}$ & $30.82 \pm 0.35^{\mathrm{a}}$ & $14.93 \pm 0.19^{\mathrm{a}}$ \\
Diet 1 & $0.00 \pm 0.00^{\mathrm{ab}}$ & $34.67 \pm 1.00^{\mathrm{ab}}$ & $0.00 \pm 0.00^{\mathrm{b}}$ \\
Diet 2 & $15.67 \pm 0.33^{\mathrm{c}}$ & $152 \pm 1.15^{\mathrm{c}}$ & $267.67 \pm 1.76^{\mathrm{c}}$ \\
Diet 3 & $0.00 \pm 0.00^{\mathrm{b}}$ & $247.47 \pm 2.19^{\mathrm{d}}$ & $55.67 \pm 1.20^{\mathrm{d}}$ \\
\hline
\end{tabular}

Data are means \pm S.E. $(n=3$ per value), expressed as $\mathrm{mg} / \mathrm{kg}$ dry weight fish. Letters with the same superscript in the same column are not significant $(\mathrm{p}>0.05)$.

Table 4 Total Copper Concentration in gill, liver and intestine of common carp fed Recovery diet (normal) for 21 days.

\begin{tabular}{llll}
\hline Treatment & Gill & Liver & Intestine \\
\hline Diet 1 & $0.00 \pm 0.00^{\mathrm{a}}$ & $34.6 \pm 1.00^{\mathrm{b}}$ & $0.00 \pm 0.00^{\mathrm{a}}$ \\
Diet 2 & $55.42 \pm 0.25^{\mathrm{b}}$ & $267.22 \pm 0.5^{\mathrm{b}}$ & $331.43 \pm 0.83^{\mathrm{b}}$ \\
Diet 3 & $364.49 \pm 5.22^{\mathrm{c}}$ & $290.99 \pm 0.70^{\mathrm{c}}$ & $78.02 \pm 0.87^{\mathrm{c}}$ \\
\hline
\end{tabular}

Data are means \pm S.E ( $\mathrm{n}=3$ per value) expressed as $\mathrm{mg} / \mathrm{kg}$ dry weight fish. Letters with the same subscript in the same column are not significant $(\mathrm{p}>0.05)$

The fact that there were observed treatment dependent effects of dietary copper exposure on osmotic balance affected and influenced haematology, which was also observed by Mazon et al., (1998). Common carp fed $1000 \mathrm{mgCu} / \mathrm{kg}$ diet showed increased haematocrit, haemoglobin, red blood cell, white blood cells, neutrophils and reduced lymphocytes. All these reflects the beginning of stress reaction of fish caused by chemicals (Folmer, 1993) as exposure of fish to heavy metal such as copper increased these haematological indices (Singh and Reddy, 1990). The increased haematological indices could possibly be the result of a diminished $\mathrm{pH}$ caused by stress-induced osmotic imbalance and changes in ion regulatory system of interchanges observed in tissue ions (sodium and potassium), (Vosyliene 1999); stress-induced epinephrine secretion which causes the spleen contraction with the release of erythrocytes from this organ into the blood and consequent increase in haematocrit (Vosyliene 1999); or a compensatory response to change in gill tissue, which probably impaired branchial gas transfer, generating an internal hypoxia which may stimulate erythrocyte-release stored in organs (spleen) into the blood circulation by adrenergic stimulation (Mazon et al., 1998). Further more, since copper is required for haemoglobin synthesis, mild excess may stimulate erythrocyte formation or release from hemopoetic tissue (Heath, 1995). The increase in haematocrit alone is related to a stress response causing red blood cell swelling (Soivo and Nikinmaa, 1981) or plasmatic volume reduction (Wilson and Taylor, 1993). Nevertheless, the increase in haematocrit coupled with the increase in red blood cell and haemoglobin, with no significant effect on MCHC, in cell size, and circulatory immature red blood cells, suggest the body's ability to absorb more oxygen from the external at environment to supply the oxygen requirement of tissue. This reflected the no visual lesion observed during exposure to elevated copper diet (Mazon et al. 1998).

Leukocytopenia has been demonstrated in teleost exposed to copper (Svobodova et al., 1994) and other heavy metal (Gill and Pant, 1986). Leucocytosis has also been recently demonstrated in similar conditions by Mazon et al., (1998). In this study, the reduced lymphocyte observed is attributed to increased leukocytes mobilization to protect the body against infections in copper-damage tissue. Initially an increase in the lymphocyte count is mostly observed during the first days of stress reaction when fish tries to restore disturbed homeostasis; however, later decrease of lymphocytes count can be observed which shows the weakening of the immune system 
(Palackova et al., 1992). This initial increase in lymphocyte was observed in this research during the acclimation of initial fish to the control diet with a moderate lymphocytic infiltrates at the base of the primary filaments of the gill and consequently decreased after 42day of exposure to the control diet. The observed significant increase in neutrophils of common carp exposed to the $1000 \mathrm{mgCu} / \mathrm{kg}$ diets after 42days have also been observed to increase in other fish (Svobodova et al., 1994). Common carp exposed to elevate copper $(2000 \mathrm{mgCu} / \mathrm{kg})$ showed decreased haematocrit close to the minimum value of normal range of 20-35\% (Clark et al., 1979), decreased haemoglobin, and red blood cells. According to Svobodova et al., (1994), high concentrations of heavy metal or long term exposure of fish to sub lethal concentrations usually decrease the haematocrit, haemoglobin, and red blood cell. A decrease in the erythrocytes count or percentage haematocrit indicates the worsening of an organism state and its developing anaemia (El-domiaty, 1987). It also indicates negative changes occurring in fish (Lebedeva et al., 1998). These changes were observed in common carp exposed to $2000 \mathrm{mgCu} / \mathrm{kg}$ diets.

Histopathological examination of initial fish and copper exposed fish tissue showed that the gills were normal during and after copper exposure. These changes have also been observed by Karan et al. (1998). No visual lesion or normal gill histological was reported also in research by Shaw and Handy (2006) on Nile tilapia fed $2000 \mathrm{mgCu} / \mathrm{kg}$ diet for 42 days. Hepatocyte (liver cells) in all treatments showed they were vacuolated (fatty change). This is the result of inability of common carp to mobilize stored fat which continued to increase even after exposure. Vacuolation of hepatocyte (fatty change in liver cells) is a common response associated with exposure to a variety of different chemicals of fish such as copper (Meyers and Henderick, 1985). This histological change could signify various biochemical lesions; inhibition of protein synthesis, energy depletion, disintegration of microtubules, and shifts in substance utilization (Meyers and Henderick, 1985). Increased hepatic copper levels resulting in vacuolated hepatocytes suggest that common carp as in other fish can redistribute accumulated copper for excretion through the liver. These changes have been observed by other authors such as Shaw and Handy (2006) and Clearwater et al. (2002). Observation in the intestine showed that in all treatments, no visual lesions were seen which indicated the homeostatic regulation of intestinal copper by fish (McDonald and Wood, 1993). Common carp exposed to elevated dietary copper showed hepatic and intestinal copper accumulation (Shaw and Handy, 2006), altered haematology and histology. The continued hepatic copper accumulation post exposure, and lipidosis, possible entero-hepatic recirculation raises concern about possible delayed toxic effect of dietary copper in fish after exposure, especially in the $2000 \mathrm{mgCu} / \mathrm{kg}$ diet on the basis of haematology such as observed signs of anaemia and severe skin discoloration. The $1000 \mathrm{mgCu} / \mathrm{kg}^{-1}$ diet could be the threshold and maximum tolerable concentration admissible in common carp based on unaltered haematology and normal gill histology, however, it should be recommended that the dietary copper requirement of fish in general and common carp in particular should not exceed physiological need of the fish to avert possible delayed hepatotoxicity. Dietary copper supplementation in excess of the requirement of common carp should be avoided.

Acknowledgements: Special thanks to God almighty for the Grace and strength to carry out this research work. Many thanks also goes to Dr E.K Ajani, university of Ibadan for his priceless role as a major supervisor and a benevolent disposition throughout the research and for having the time to edit this masterpiece of a work, who also acted as a co-author. To Prof S.O Akpavie, department of veterinary medicine, university of Ibadan for his contributions in the histology of the tissues used in the research.

\section{REFERENCES}

Alabaster, J.S and Lloyd, R. (1980). Water quality criteria for freshwater fish. Butterworths. Pp. 297.

Chakrabarty, R.D (1982). Polyculture principles and practices. J. Inland Fisheries. 1: 30-40.

Clark S.D.H(Jr) Whitemore, R, McMahon, F. (1979). Consideration of blood parameters of largemouth, bass (Macropterus salmoides) J. Fish biology 14: $147-154$.

Clearwater S. J, Farag, A.M., and Meyer, J.S. (2002) Bioavailability and Toxicity of diet borne copper and zinc to fish, Comp. Biochem. Physiol. 132: 269 -313 .

El-Dormiaty N.A (1987). Stress response of juvenile Clarias lazera elicited by copper. Comp. Bioch. and Physiol. (2): $259-262$.

Folmar, J.C (1993). Effects of chemical contaminants on blood chemistry of teleost fish: a bibliography and synopsis of selected effects. Environ. Toxicol. Chem. 12: $337-375$.

Gill, T.S and Plant, J.C. (1986). Chromatin condensation in the erythrocytes of fish following exposure to cadmium. Bull. Environ. Contam. Toxicol. 36: 199203.

Handy, R.D, Sims, D.W, Giles, A, Cambell, H.A and Musonda, M.M. (1999). Metabolic

trade-off between locomotion and detoxification for maintenance of blood chemistry and growth 
parameters by rainbow trout (Oncorhynchus mykiss) during chronic dietary exposure to copper. Aquat. Toxicol. 47: $23-41$.

Heath, A.G. (1995). Water pollution and fish physiology. CRC Press, Boca Ration, Florida, USA. Pp. 56-78.

Jain, N.S (1986). Schalm's veterinary haematology (Jain, N.C, ed), $4^{\text {th }}$ edition, lea and Ferbinger, Philadelphia. Pp. 86.

Karan,V, Vitorovic, S, Tutudzic, V and Poleksic, V. (1998). Functional enzymes Activity and Gill histology of carp after copper sulfate Exposure and Recovery. Ecotoxicol. Environ. Saf. 40: 49-55.

Lebedeva N.E, Vosyliene,V.Z , Golovkina,T.V (1998) Haematological and biochemical response of fish to biogenous and anthropogenic chemical stimuli. Ichthyohaematology. Proceedings of the $4^{\text {th }}$ Ichthyohaematological conference, Czech. Pp. 85 87.

Linder, M.C (1991) Biochemistry of copper, plenium press, New York. Pp. 34-45.

Mazon, A.F, Fernandes, M.N., Nolasco, M and Severi, W. (1998). Functional morphology of gill and respiratory area of two active rheophilic fish species, Plagloscion Squamosissimus and Prochilodus Scrofa. Brazilian J. Bio. 52: 50 - 61.

McDonald, D.G and Wood, C.M. (1993) Branchial mechanisms of acclimation to metals in freshwater fish. In: Fish ecophysiology (ed. J.C. Rankin and F.B. Jensen), London, UK: Chapman and Hall. Pp. $297-321$.

Meyers, R and Hendricks, J.D (1985). Histopathology In: fundamentals of aquatic Toxicology, (eds) G.M.R and S. R Petrocelli, Washington, D.C: Hemisphere Publishing Corp. Pp. $283-331$.

Moore, B.K, Mitchell, A.J , Griffin, B.R and Huffman, G.L. (1984). Parasite and diseases of pond fishes. Third report of the fish farmers: US fish and wildlife services, Washington. D.C. Pp. 56.

Nathaniel, S and Edirisinghe, U. (2001). Abundance and aspects of the reproductive biology of Common Carp (Cyprinus Carpio) in an upland Reservoir in Srilanka. Asian Fisheries Sci. 14: 343 - 351.
Okoye,B.C.C., Ogunlowo,S.O and Nwankwoala, A.U. (1991). Heavy metals in organisms in the Lagos lagoon. Int. J. Environ. Stud. 37:285-292.

Palackova, J, Pravda, D, Fasaic, K and Celechovska, O. (1992). Sub lethal physiological effects of cadmium on carp (Cyprinus carpio) fingerlings. EIFAC/XVII92/Symp. E7.

Panek, F. M (1987). Biology and Ecology of carp. Cooper, E.L. (editor) Carp in North America. American fisheries society, Bethesda, Maryland, USA. Pp. 116.

Shaw, B. J and Handy, R. D. (2006). Dietary Copper exposure and Recovery in Nile Tilapia. Aquatic Toxicol. 76 (2): 111-121.

Singh,H.S and Reddy, R.V. (1990). Effect of copper sulphate on haematology, blood chemistry and hepatosomatic index of an Indian catfish, Heteropneustes fossilis (Bloch), and its recovery. Ecotoxicol. Environ. Safety. 20: 30-35.

Soivo, A and Nikinmaa, A. (1981). The swelling of erythrocytes in relation to the oxygen affinity of the rainbow trout, Salmi gairdneri. In: stress and fish. Richardson A.D.Pickering (ed), Academic. London. Pp. 34.

Svobodova,Z, Vykusova, B and Machova, J. (1994). The effects of pollutants on selected haematological and biochemical parameters in fish. In: sub lethal and chronic effects of pollutants on freshwater fish. Muller and Lloyd (eds) Fishing News Books, London. Pp.21.

Taylor,J and Mahon, R. (1977). Hybridisation of Cyprinus carpio and Carassius auratus, the first two exotic species in the lower Laurentian Great lakes. Environ. Biol. fishes. 1(2): 205-208.

Vosyliene M.Z (1999). The effect of heavy metal mixture on haematological parameters of rainbow trout. In: Heavy metals in the environment. An integrated approach. Ed. D. A. Lovejoy. Pp. 295 - 298.

Wilson, R.W and Taylor, E.W. (1993). The physiological responses of freshwater rainbow trout, Oncorhynchus mykiss, during acutely lethal copper exposure. J. Comp. Physiol. 163: 38 - 47. 